\title{
PENGEMBANGAN KAWASAN OBJEK WISATA BONO TELUK MERANTI DENGAN PENDEKATAN TRANSFORMASI ARSITEKTUR MELAYU
}

\author{
WAN SULFAH RINALDI, HENDRI SILVA, IMBARDI \\ Program Studi Arsitektur, Fakultas Teknik, Universitas Lancang Kuning \\ Jl. Yos Sudarso km. 8 Rumbai, Pekanbaru, Telp. (0761) 52324 \\ Email: onecuelfahrinaldi05@gmail.com
}

\begin{abstract}
ABSTRAK
Bono adalah fenomena alam yang menjadi salah satu potensi yang terdapat pada objek wisata di kecamatan Teluk Meranti kabupaten Pelalawan. Salah satu persoalan dari pengembangan wisata Bono ini tidak hanya terdapat pada infrastrukturnya saja, namun juga terdapat pada persoalan sarana akomodasi khususnya fasilitas penginapan (Hotel). Tujuan dari pembahasan ini adalah untuk tersusunnya perencanaan dan pemogramam serta konsep dari Pengembangan Kawasan Objek Wisata Bono. Sasaran dalam pengembangan ini yaitu untuk mewadahi kegiatan pariwisataan dalam bentuk wisata rekreasi dan penginapan (resort). Adapun metode penelitiannya yaitu analisis terhadap aspek potensi Bono sebagai objek wisata, aspek manusia sebagai pengguna, aspek lingkungan dan tapak sebagai konteks dan aspek bangunan sebagai sarana dan prasarana. Adapun hasil yang di dapat berupa program rancangan, konsep rancangan dengan pendekatan yang selanjutnya di transformasikan kedalam bentuk desain berupa permodelan.
\end{abstract}

Kata kunci: Wisata Bono, Pengembangan Kawasan, Resort.

\section{ABSTRACT}

Bono is a natural phenomenon which is one of the potential found in tourism objects in Teluk Meranti district, Pelalawan district. One of the problems of developing Bono tourism is not only in its infrastructure, but also in the problem of accommodation facilities, especially lodging facilities (hotels). The purpose of this discussion is to arrange planning and programming as well as concepts from the Development of Bono Tourism Object Areas. The target in this development is to accommodate tourism activities in the form of recreational tourism and lodging. The research method is an analysis of the potential aspects of Bono as a tourist object, human aspects as user, environmental aspects and site as the context and aspects of the building as facilities and infrastructure. The results can be in the form of a design program, the design concept with the approach which is then transformed into a form of modeling.

Keywords: Bono Tourism, Area Development, Resort.

\section{PENDAHULUAN}

Bono, adalah fenomena alam yang menjadi salah satu potensi yang terdapat pada objek wisata di Kecamatan Teluk Meranti, Kabupaten Pelalawan. Persoalan dari pengembangan wisata Bono ini tidak hanya terdapat pada infrastrukturnya saja, namun juga terdapat pada sarana akomodasi seperti fasilitas penginapan (Hotel). Bahwasanya untuk lebih meningkatkan daya tarik dan produktivitas dari objek wisata Bono, sudah seharusnya disusun suatu konsep pengembangan yang terpadu dan ber-kesinambungan, dengan konteks mengkombinasi-kan arsitektur masa kini dan mengambil nilainilai arsitektur tradisional agar sebuah desain yang di rancang tidak menghapus identitas dari lokasi perencanaan. Upaya pengembangan objek wisata bono ini telah di usahakan Pemerintah Kabupaten Pelalawan yang disusun dengan 4 tahapan yang di mulai dari tahun 2014-2030.

Hingga saat ini jalan yang menghubungkan antara ibukota kabupaten yaitu kota Pangkalan Kerinci dengan kawasan objek wisata Bono masih dalam proses pengerjaan, dimana rute menuju Kecamatan Teluk
Meranti (Objek Wisata Bono) dari Provinsi Pekanbaru dapat dilakukan melalui jalur Jalan Lintas Timur Sumatera yang menghubungkan dari Pekanbaru, Pangkalan Kerinci dan Sorek (Ibukota Kecamatan Pangkalan Kuras) untuk kemudian berbelok ke arah timur melalui Kecamatan Pangkalan Bunut dan menyambung ke Kecamatan Teluk Meranti (Objek Wisata Bono). Dimana perjalanan menggunakan akses darat dari Provinsi Pekanbaru hingga ke Kacamatan Teluk Meranti akan memakan waktu 6-7 jam. Berikut peta rute Provinsi Pekanbaru menuju Kecamatan Teluk Meranti (Objek Wisata Bono).

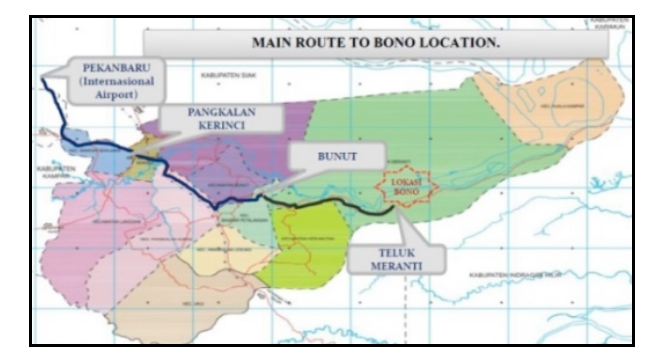

Gambar 01. Peta Rute Pekanbaru Sampai Teluk Meranti. (Sumber: dpmptsp.riau.go.id) 


\section{METODE PENELITIAN}

Metode pengumpulan data dari Pengambangan Kawasan Obyek Wisata Bono Teluk Meranti yang dibutuhkan untuk menjawab permasalahan arsitektur yang ada, adalah sebagai berikut:

\subsection{Survei Lapangan.}

Melakukan peninjauan dan pengamatan langsung pada lokasi yang akan dijadikan objek perancangan dengan mengambil data berupa foto.

\subsection{Studi Literatur.}

Studi literatur yaitu berupa buku maupun data di internet yang dapat memberikan keterangan ataupun penjelasan yang terkait judul secara tertulis.

\subsection{Studi Banding.}

Melakukan penelitian secara langsung maupun tidak langsung terhadap bangunan yang sejenis melalui bantuan internet, maupun survey kelokasi yang berkaitan dengan data yang diinginkan.

\subsection{Observasi.}

Mendapatkan informasi yang dibutuhkan dengan cara mengajukan beberapa pertanyaan kepada pihak yang terkait yang berhubungan dengan judul.

\section{HASIL DAN PEMBAHASAN}

\subsection{Persyaratan Objek Wisata.}

Persyaratan pengembangan suatu objek wisata harus di lihat dari prasarana dan sarana pariwisata itu sendiri. Dimana, 'prasarana pariwisata' adalah segala sesuatu yang memungkinkan proses kegiatan pariwisata dapat berjalan, misalnya: perangkutan, komunikasi, dan sumber energi dan sesuatu yang mungkin dapat dikatakan murni sebagai prasarana pariwisata adalah 'daya tarik wisata'. Selain prasarana fisik, ada faktor lain bersifat kualitatif yang menjadi 'prasyarat' pengembangan pariwisata yakni 'keamanan', seperti: keberadaan aparat keamanan, keberadaan pos-pos keamanan, kelengkapan dan perlengkapan keamanan.

Sedangkan 'sarana pariwisata' adalah segala sesuatu yang melengkapi dan atau memudahkan proses kegiatan pariwisata berjalan, seperti: penginapan, rumah makan, perbelanjaan, biro perjalanan, lembaga keuangan, dan lain-lain. Sarana pariwisata adalah fasilitas yang harus diadakan apabila suatu DTW (Daerah Tujuan Wisata) ingin dikembangkan. Ketersediaan prasarana dan sarana akan memperkuat DTW yang bersangkutan, terutama bila akses ke DTW sangat dipermudah.

\subsection{Resort Hotel.}

Resort Hotel didefinisikan sebagai hotel yang terletak di kawasan wisata, dimana sebagian pengunjung yang menginap tidak melakukan kegiatan usaha. Umumnya terletak cukup jauh dari pusat kota sekaligus di fungsikan sebagai tempat peristirahatan. Sehingga kesimpulan dari Resort Hotel adalah suatu sarana akomodasi yang menyediakan fasilitas untuk berlibur, rekreasi, olah raga, dan juga umumnya tidak di pisahkan dari kegiatan menginap bagi pengunjung. Dimana karakteristik Hotel Resort yaitu terletak pada 1) Lokasi, 2) Fasilitas, 3) Arsitektur dan Suasana, 4) Segmen Pasar.

\subsection{Arsitektur Melayu.}

Kata Melayu berasal dari kata "Mala" dan "Yu". Mala artinya mula atau permulaan, sedangkan Yu berarti negeri. Melayu berarti negeri yang mula-mula ada. Pendapat ini sesuai dengan perkembangan bangsa Melayu dari daratan Asia Tenggara, pada kira-kira tahun 2000 SM dan 1500 SM yang menyebar keseluruh Indonesia. Jalan yang mereka lewati adalah Indonesia bagian Barat melalui Semenanjung Malaya, Sumatera dan Jawa dan melewati wilayah pulau-pulau Riau.

Mangunwijaya dalam Wastu Citra (1988) menyebutkan arsitektur terdiri atas:

3.3.1. Guna - Citra (Fungsi dan Estetika).

Fungsi dan estetika dari arsitektur melayu tediri dari 2 (dua) tipologi, yaitu:

1. Tipologi ini dilihat dari fungsi akan bangunan itu sendiri, seperti: Rumah Tinggal, Rumah Ibadah, Istana, Rumah Balai, dan Lumbung Padi.
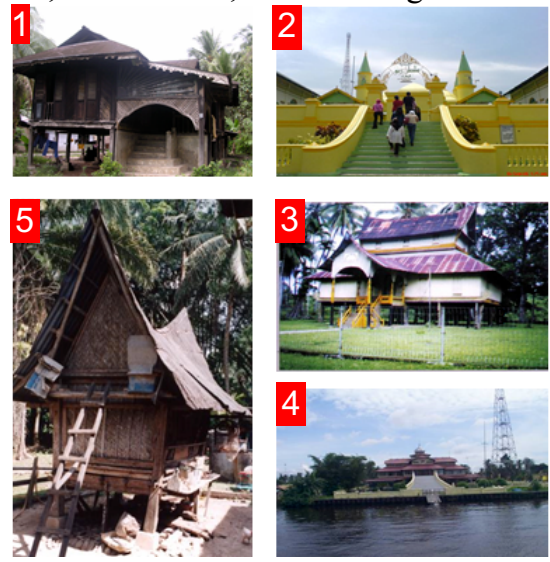

Gambar 02. Tipologi Fungsi: 1. Rumah Tinggal, 2.

Rumah Ibadah, 3. Istana, 4. Rumah Balai, 5. Lumbung Padi.

(Sumber: Ir. Sudarmin, M.T.)

2. Tipologi Atap, terdiri dari: Pondok Pisang Sesikat, Atap Lipat, Atap Lontiok, Dan Atap Limas.
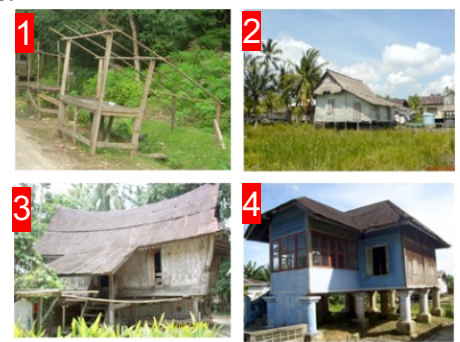

Gambar 03. Tipologi Atap: 1. Pondok Pisang Sesikat, 2. Atap Lipat, 3. Atap Lontiok, 4. Atap Limas. (Sumber: Ir. Sudarmin, M.T.) 


\subsubsection{Gatra - Ruang (Massa dan Ruang).}

Rumah tradisional melayu adalah rumah panggung dengan konstruksi rangka kayu. Struktur pembentuk massa bangunan dari rumah tradisional melayu, yaitu: Pondasi, Rangka Lantai, Rangka Dinding, Rangka Loteng, dan Rangka Atap.

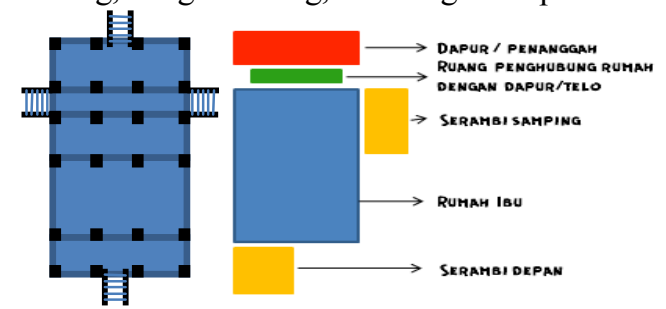

Gambar 04. Bentuk Massa Bangunan \& Struktut Rumah Atap Lipat.

(Sumber: Ir. Sudarmin, M.T.)

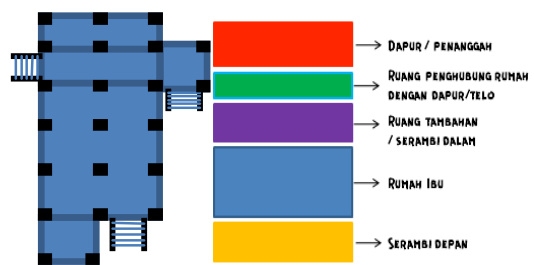

Gambar 05. Bentuk Massa Bangunan \& Struktut Rumah Atap Limas.

(Sumber: Ir. Sudarmin, M.T.)

\subsection{Studi Banding.}

Studi Banding merupakan suatu kegiatan yang dilakukan dengan tujuan menambah wawasan dan pengetahuan yang akan diterapkan kedepannya untuk menjadi lebih baik. Dimana hasil studi banding akan tertuju pada objek wisata pantai dan akomodasi seperti hotel.

Tabel 1. Studi Banding Objek Wisata Pantai.

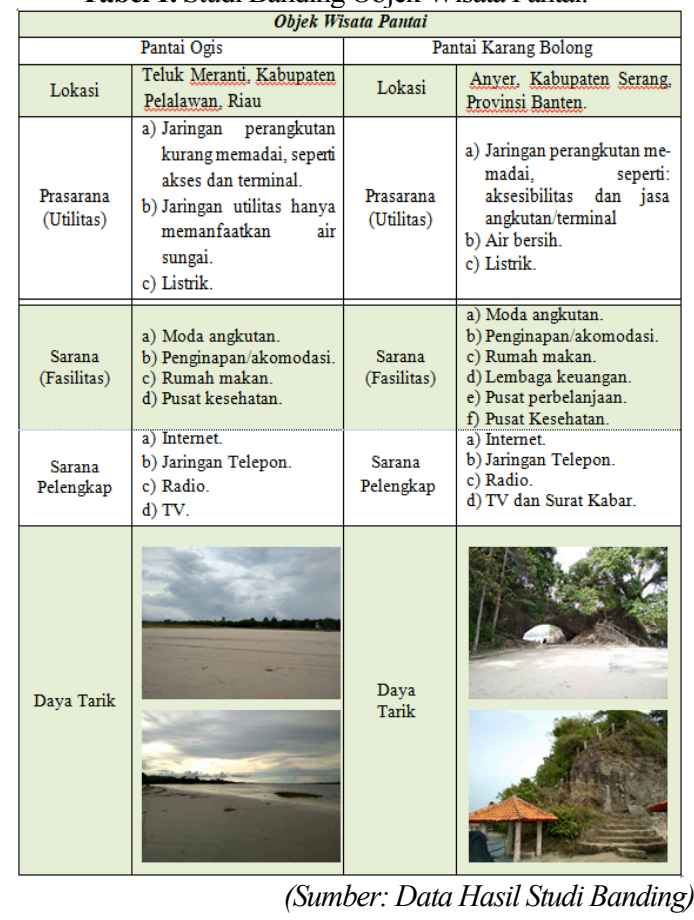

Tabel 2. Studi Banding Hotel Resort.

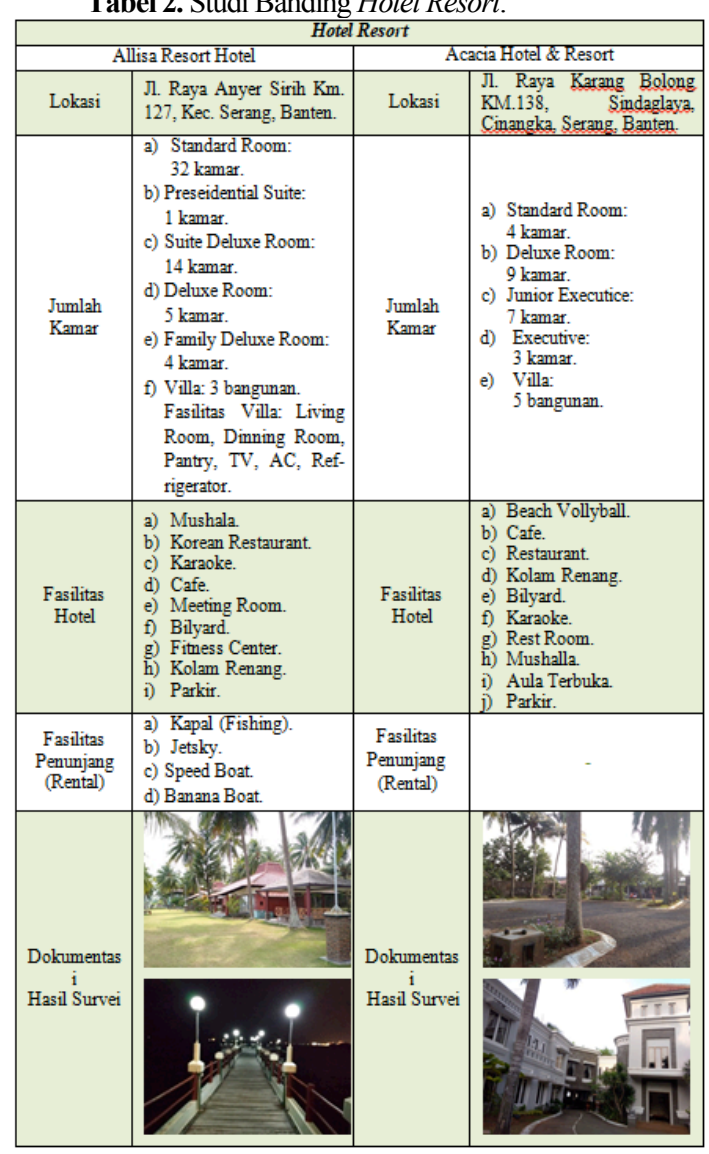

(Sumber: Data Hasil Studi Banding)

\subsection{Tinjauan Kontekstual.}

Bono, adalah fenomena alam yang menjadi salah satu potensi yang terdapat pada objek wisata di Kecamatan Teluk Meranti, Kabupaten Pelalawan. Dimana bono biasanya terjadi pada kurun waktu $2 \mathrm{x}$ dalam sebulan. Sebelum terjadinya gelombang Bono, biasanya akan diawali dengan bunyi desingan, selanjutnya akan terdengar bunyi gemuruh air. Bunyi gemuruh tersebut semakin lama akan semakin keras dan muncul lah gelombang besar yang disebut dengan Bono. Kecepatan dari gelombang ombak Bono mencapai $40 \mathrm{~km} / \mathrm{jam}$.Ombak ini mampu memasuki ke arah hulu sungai berkilo-kilo meter jauhnya.

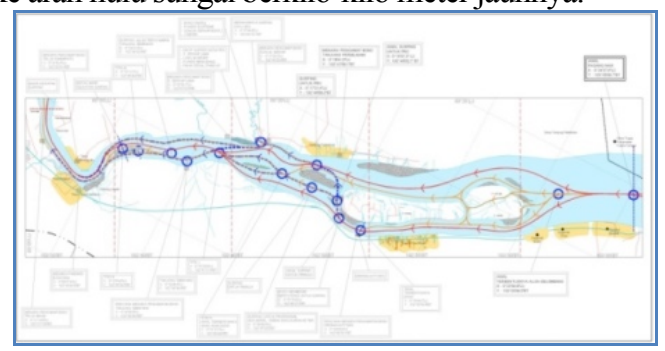

Gambar 07. Peta Posisi Terbentuknya Gelombang Pasang (Bono)..

(Sumber: Dinas Kebudayaan, Pariwisata, Pemuda Dan Olahraga Kabupaten Pelalawan) 
Sarana akomodasi yang berada di Teluk Meranti seperti hotel atau penginapan sangat kurang mendukung dalam bentuk persyaratan yang dibutuhkan pada sebuah kawasan objek wisata.. Dimana akomodasi pada lokasi masih berbentuk bangunan sederhana hingga keamanan dan kenyamanannya belum ada.

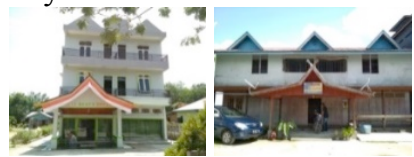

Gambar 08. Hotel \& Penginapan di Teluk Meranti. (Sumber: Dokumentasi Hasil Survei)

Dalam Perencanaan Penataan Dan Pengambangan Obyek Wisata Bono telah ditetapkan bahwa lokasi terletak di yang terletak di pesisir Selatan dari Sungai Kampar, terletak di sebelah Timur dari Kota Teluk Meranti dan berada di sebelah Barat dari Desa Pulau Muda. Dimana sesuai Peraturan Bupati Pelalawan terletak pada Pasal 5 Ayat (1) Pemerintah Daerah menetapkan lahan seluas 600 hektar di Kecamatan Teluk Meranti sebagai KSPD Bono.

Secara geografis lokasi area yang dipersiapkan untuk pengembangan fasilitas Pendukung Kepariwisataan Bono Kampar ini adalah memiliki dimensi, selebar $1 \mathrm{~km}$ dari garis Pantai Selatan Sungai Kampar, memanjang sepanjang $6 \mathrm{~km}$.

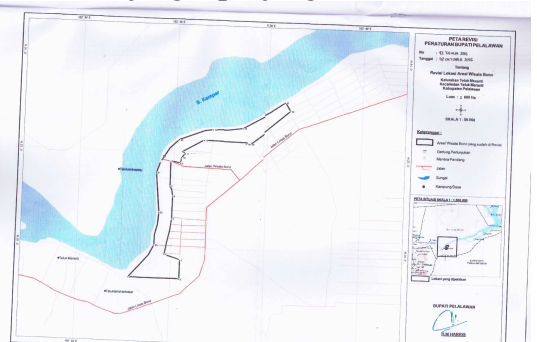

Gambar 09. Lokasi Site Kawasan Objek Wisata Bono. (Sumber: Dinas Kebudayaan, Pariwisata, Pemuda Dan Olahraga Kabupaten Pelalawan)

\subsection{Analisis Program Kegiatan Wisata Bono}

Analisis di bertujuan untuk mengetahui kegiatan pada kawasan Wisata Bono dengan mengelompokkan tiap zona dengan kegiatan dan fasilitasnya.

Tabel 3. Analisis Penentuan Ruang.

\begin{tabular}{|c|c|c|}
\hline Zona & Kegiatan / Aktifitas & Fasilitas \\
\hline \multirow{14}{*}{ Bangunan. } & \multicolumn{2}{|c|}{ Fasilitas Utama } \\
\hline & Menginap & Resort \\
\hline & \multicolumn{2}{|c|}{ Fasilitas Penunjang } \\
\hline & Ibadah. & Masjid. \\
\hline & $\begin{array}{l}\text { Menyewa \& membeli alat } \\
\text { olahraga Surfing. }\end{array}$ & Plaza Surf and Sport \\
\hline & Makan dan Minum & Food court. \\
\hline & \multicolumn{2}{|c|}{ Administratif } \\
\hline & $\begin{array}{l}\text { Kegiatan mengelola dan } \\
\text { mengepalai kawasan wisata. }\end{array}$ & $\begin{array}{l}\text { Ruang direktur dan wakil } \\
\text { direktur. }\end{array}$ \\
\hline & Mengurusi urusan sekretaris. & Ruang sekretaris. \\
\hline & Mengurusi urusan resort & Ruang manager \\
\hline & Mengurusi bagian keuangan. & Ruang bagian keuangan. \\
\hline & $\begin{array}{l}\text { Mengurusi kegiatan } \\
\text { operasional. }\end{array}$ & Ruang bagian operasional. \\
\hline & $\begin{array}{l}\text { Mengurusi kegiatan } \\
\text { administrasi. }\end{array}$ & $\begin{array}{l}\text { Ruang bagian } \\
\text { administrasi. }\end{array}$ \\
\hline & $\begin{array}{l}\text { Mengurusi kegiatan } \\
\text { personalia. }\end{array}$ & Ruang bagian personalia. \\
\hline
\end{tabular}

\begin{tabular}{|c|c|c|}
\hline \multirow{15}{*}{ Wisata. } & \multicolumn{2}{|c|}{ Area Penerimaan } \\
\hline & Memarkir kendaraan & Area Parkir \\
\hline & Pembelian tiket. & Loket tiket \\
\hline & \multicolumn{2}{|c|}{ Wisata Rekreatif } \\
\hline & Kegiatan Surfing & Dermaga. \\
\hline & Kegiatan bermain. & Water Park. \\
\hline & Kegiatan Olahraga & Flow Ride \& Kayaking. \\
\hline & \multicolumn{2}{|c|}{ Servis } \\
\hline & $\begin{array}{l}\text { BAK/BAB, membilas \& } \\
\text { mengganti pakaian. }\end{array}$ & Lavatory. \\
\hline & Keselamatan. & R. P3K \& Viewing Tower: \\
\hline & Pengamanan. & Pos jaga (Security). \\
\hline & Kebersihan. & Ruang Tenaga Kebersihan. \\
\hline & M.E. & Ruang M.E. \\
\hline & Perawatan kawasan wisata. & Ruang maintenance. \\
\hline & Istirahat. & Gazebo. \\
\hline
\end{tabular}

Tabel 4. Rekapitulasi Besaran Ruang.

\begin{tabular}{|c|c|c|}
\hline \multicolumn{3}{|c|}{ Rekapitulasi Zona Bangunan. } \\
\hline No. & Zona Fasilitas & Luas \\
\hline 1 & Resort. & 7154.472 \\
\hline 2 & Fasilitas Penunjang & 738.852 \\
\hline 3 & Administrasi & 230.4 \\
\hline & Total & 8123.724 \\
\hline \multicolumn{3}{|c|}{ Rekapitulasi Wisata. } \\
\hline No. & Zona Fasilitas & Luas \\
\hline 1 & Penerimaan. & 1551 \\
\hline 2 & Wisata Rekreatif. & 1347.78 \\
\hline 3 & Kegiatan Servis. & 1425.852 \\
\hline & Total & 11478.852 \\
\hline \multicolumn{3}{|c|}{ Rekapitulasi Zona Bangunan. } \\
\hline No. & Zona Fasilitas & Luas \\
\hline 1 & Bangunan. & 8123.724 \\
\hline 2 & Wisata. & 11478.852 \\
\hline & Total & 12448.104 \\
\hline
\end{tabular}

\subsection{Analisis Lingkungan.}

Analisis terdiri dari beberapa aspek antara lain:

\subsubsection{Pencapaian.Tapak.}

Tapak dilewati oleh satu jalur yaitu Jalan Lintas Bono, dimana jalan tersebut telah di ratakan dan masuk kedalam proses peng-aspalan. Kurang lebih jalan yang belum ber-aspal untuk sampai ke lokasi yaitu $30 \mathrm{~km}$, sedangkan dermaga untuk jalur sungai terdapat langsung di permukiman warga Teluk Meranti.

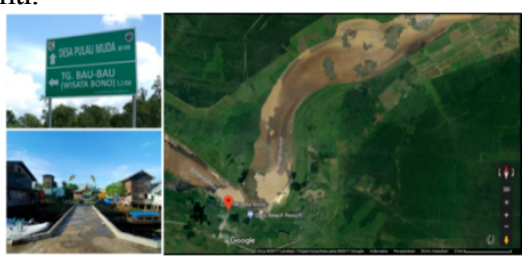

Gambar 10. Peta Pencapaian Lokasi Tapak. (Sumber: Dokumentasi Hasil Survei)

\subsubsection{Dampak Ombak Bono.}

Karena Kawasan Wisata Bono ini terletak pada daerah dataran rendah dan merupakan daerah hilir dari sungai Kampar yang dipengaruhi oleh Pasang surut air laut yang bisa membentuk gelombang dengan kecepatan $10 \mathrm{~s} / \mathrm{d} 15 \mathrm{~km} / \mathrm{jam}$ ini bisa mengakibatkan hancurnya tebing sungai di daerah yang dilewati oleh gelombang pasang dan 
dimana tingkat kebisihan tertinggi pada tapak terjadi $2 \mathrm{x} /$ bulan, selain itu dampak dari gelombang pasang (Bono) yaitu dengan naiknya air sungai hingga di permukaan tanah $\pm 50 \mathrm{~cm}$ \& panjang luapan Gelombang Pasang Surut (Bono) 40-50 m.

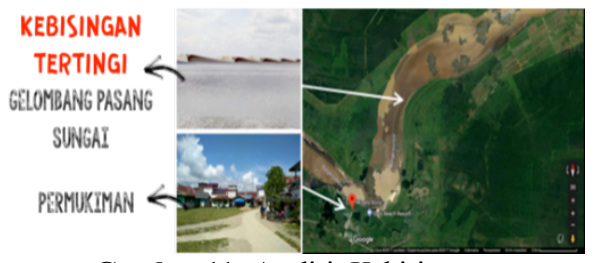

Gambar 11 . Analisis Kebisingan.

(Sumber: Dokumentasi Hasil Survei)

Respon terhadap dampak dari gelombang bono:

1. Memanfaatkan suara kebisingan ombak sebagai tanda munculnya Bono bagi wisatawan yang berkunjung.

2. Menyediakan Shelter \& Viewing Tower, untuk memanfaatkan potensi Gelombang Pasang Surut (Bono).

5.7.3. View dan Orientasi Matahari.

View yang terlihat menarik jika dilihat dari tapak adalah view yang mengarah ke Sungai Kampar, yang mengarah langsung ke Daya Tarik Wisata itu sendiri (Bono). Sedangkan view dari bagian lainnya hanya di penuhi dengan pepohonan.

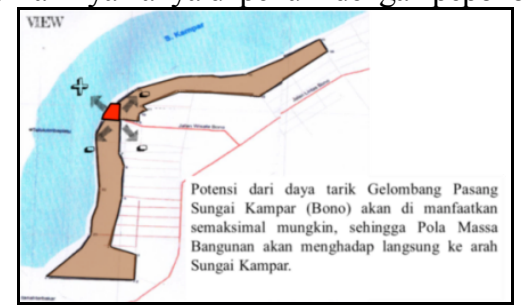

Gambar 12 . Respon Analisis View. (Sumber: Hasil Analisis Penulis)

Sedangkan perkiraan cuaca pada lokasi site/tapak:

1. Pada pagi hari kisaran pukul 06.00-08.00 sinar matahari cenderung hangat dan menyehatkan bagi tubuh.

2. Menjelang siang kisaran pukul 08.00-15.00 sinar matahari cenderung panas menyengat.

3. Kisaran pukul 16.00-18.00 sinar matahari mulai berkurang intensitas panasnya.

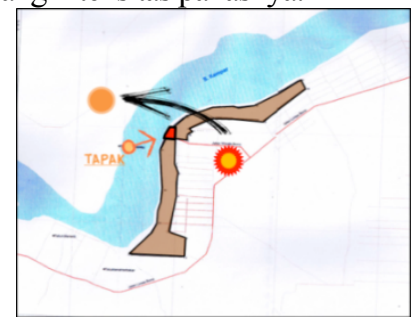

Gambar 13. Orientasi Matahri.

(Sumber: Hasil Analisis Penulis)

Respon terhadap orientasi matahari:

1. Penataan massa bangunan pada lokasi tapak akan menggunakan sudut 300, dengan mempertimbangkan respon akan view dan orientasi matahari.

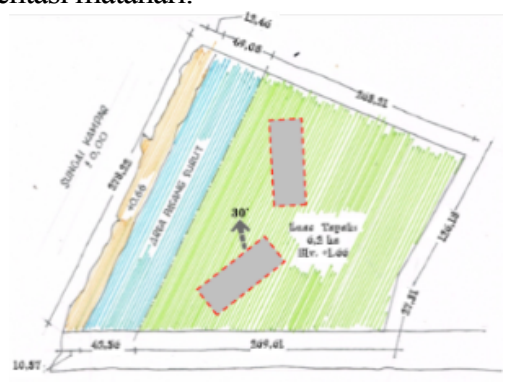

Gambar 14 . Penggunaan Sudut $30^{0}$ Pada Bangunan.

(Sumber: Hasil Analisis Penulis)

2. Dampak akan panas matahari akan menerapkan beberapa unsur, seperti:

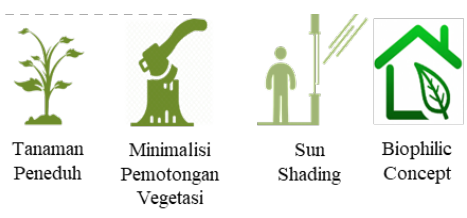

mbar 15. Respon Terhadap Orientasi Matahari. (Sumber: Hasil Analisis Penulis)

5.7.4. Kontur.

Dalam wilayah Kabupaten Pelalawan selain sungai utama yaitu Sungai Kampar, terdapat juga anak-anak sungainya Sejalan dengan pola umum topografi tersebut keberadaan Sungai Kampar dan anak-anak sungainya, dapat diindikasikan bentuk lahannya terdiri dari: Dataran aluvial, Dataran gambut, Dataran peralihan, \& Perbukitan. Namun kondisi dataran pada lokasi site/tapak yang ada di Teluk Meranti yaitu Dataran Gambut dan kontur pada tapak relatif datar berkontur / memiliki kelerengan $0-2 \%$.

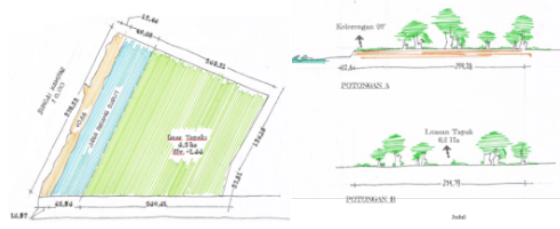

Gambar 16. Analisis Topografi (Sumber: Hasil Analisis Penulis)

5.7.5.Zoning.

Pentahapan penzoningan tapak akan di lihat dari hasil beberapa analisis yang telah dilakukan, berikut hasil dari analisis penzoningan.

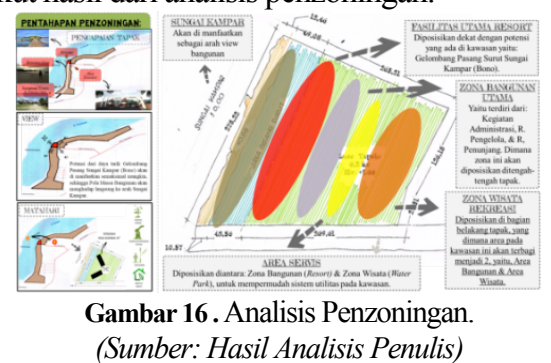




\subsection{Analisis Wisata.}

Dari hasil studi lapangan dan analisis yang telah dilakukan, dapat disimpulkan bahwa daerah Kecamatan Teluk Meranti terdapat beberapa potensi yang mendukung untuk menciptakan kawasan wisata yang ideal. Namun potensi utama (Ombak Bono) yang terdapat di Teluk Meranti ini masih memiliki sedikit kekurangan, yaitu terdapatnya jadwal atau waktu munculnya ombak tersebut. Sehingga untuk menutupi atau menambah daya tarik pada kawasan Teluk Meranti, maka segala aspek potensi yang terdapat di kawasan akan di pergunakan semaksimal mungkin. Berikut respon untuk menambah daya tarik dari kawasan Teluk Meranti:

Tabel 4. Respon Analisis Wisata.

\begin{tabular}{|l|l|}
\hline \multicolumn{1}{|c|}{ Potensi } & \multicolumn{2}{|c|}{ Respon } \\
\hline $\begin{array}{l}\text { 1. Gelombang Pasang } \\
\text { Sungai Kampar } \\
\text { (Bono). }\end{array}$ & $\begin{array}{l}\text { 1. Menciptakan daya } \\
\text { tarik penunjang } \\
\text { (Flow Ride). }\end{array}$ \\
& $\begin{array}{l}\text { 2. Menambah wisata } \\
\text { rekreasi, seperti: } \\
\text { Kayaking. }\end{array}$ \\
2. Pantai Ogis \& Satwa & \multicolumn{2}{|c|}{} \\
\hline \multicolumn{2}{|c|}{ Hutan Keru-mutan } \\
\hline
\end{tabular}

\subsection{Analisis Bangunan.}

Bertujuan untuk menganalisis akan berbagai aspek dari sebuah tema, sistem sirkulasi, pola parkir, dan sistem struktur.

5.9.1. Tema.

Konteks yang diambil dari tema Arsitektur Melayu yaitu mengkombinasikan arsitektur masa kini dan mengambil nilai-nilai arsitektur tradisional agar sebuah desain yang di rancang tidak menghapus identitas dari lokasi perencanaan.
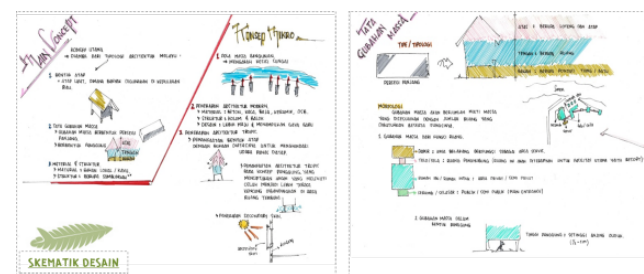

Gambar 17. Transformasi Arsitektur Melayu. (Sumber: Hasil Analisis Penulis)

\subsubsection{Sistem Sirkulasi.}

Sistem sirkulasi penghubung antar zona terdiri dari beberapa jenis sistem, antara lain:
Tabel 5. Jenis-jenis sistem sirkulasi.

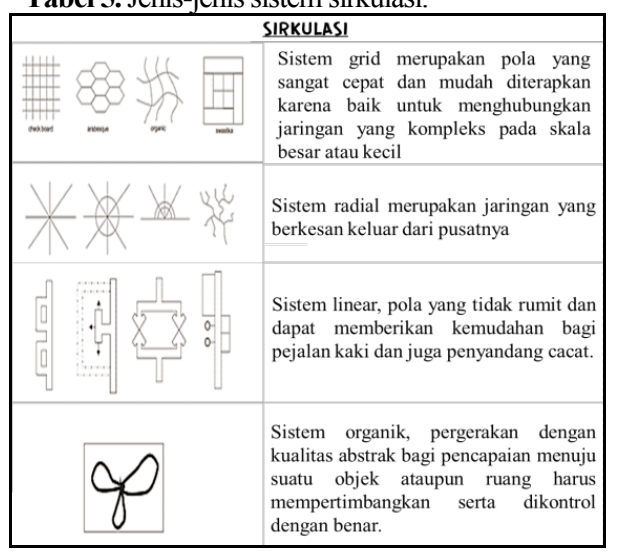

(Sumber: Hasil Analisis Penulis)

Respon dari sistem sirkulasinya, yaitu:

1. Jalur penghubung antar zona akan menggunakan pola dari sistem sirkulasi linear.

2. Penambahan dermaga yang bertujuan untuk mempermudah wisatawan yang dating melewati Sungai Kampar.

3. Sistem sirkulasi pada bangunan menggunakan 2 (dua) sistem sirkulasi, yaitu: Sirkulasi Horizontal (selasar, jembatan dan koridor) dan Sistem Sirkulasi Vertikal (tangga dan lift).

5.9.3. Pola Parkir.

Sistem perparkiran pada Kawasan Objek Wisata Bono akan menggunakan sistem parkir menyudut 90o, yang dikarenakan memiliki daya tampung yang besar, manuver dan sirkulasi keluar masuk kendaraan yang mudah.

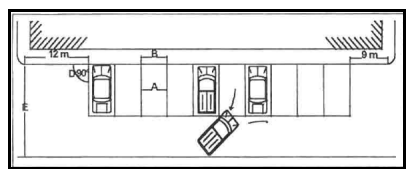

Gambar 18. Poela Parkir $90^{\circ}$.

(Sumber: Hasil Analisis Penulis)

5.9.4. Sistem Struktur.

Analisis ini bertujuan untuk menentukan sub structure, super structure, dan upper structure.

1. Sub structure.

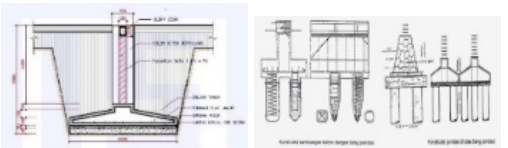

Gambar 19. Pondasi Plat Beton \& Tiang Pancang. (Sumber: Hasil Analisis Penulis)

2. Super structure.

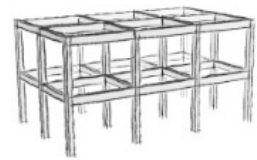

Gambar 20. Sistem Struktur Kolom \& Balok. (Sumber: Hasil Analisis Penulis) 
3. Upper structure.

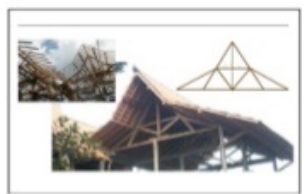

Gambar 21. Sistem Rangka Batang (Sumber: Hasil Analisis Penulis)

\subsection{Konsep Penataan Gubahan Massa.}

Konsep ini akan diambil dari hasil analisis sistem sirkulasi yang menggunakan sistem linear dan dermaga sedangkan konsep dari tata gubahan akan dilihat dari beberapa aspek:

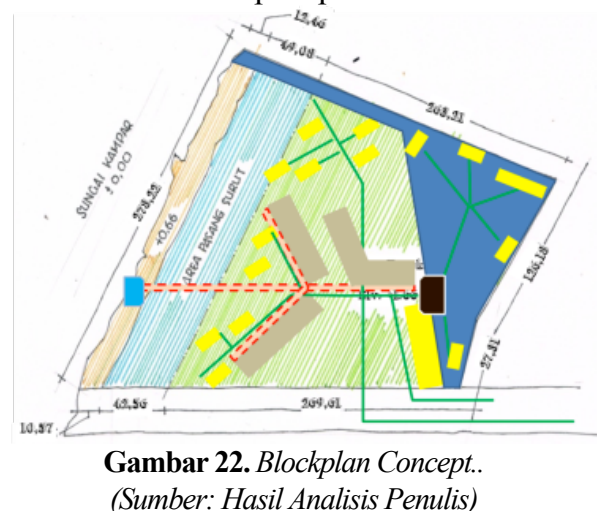

\subsection{Konsep Bentuk Bangunan,}

Konsep bentuk bangunan pada Pengembangan Kawasan Objek Wisata Bono akan diambil dari suatu rangkaian hasil analisis. Berikut konsep bentuk bangunan pada Pengembangan Kawasan Objek Wisata Bono:

5.11.1. Konsep Bentuk Bangunan Zona Penerimaan.

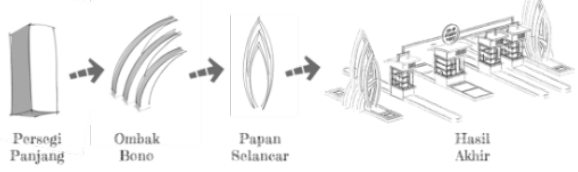

Gambar 23. Bentuk Bangunan Gate. (Sumber: Hasil Analisis Penulis)

5.11.2. Konsep Bentuk Bangunan Utama.

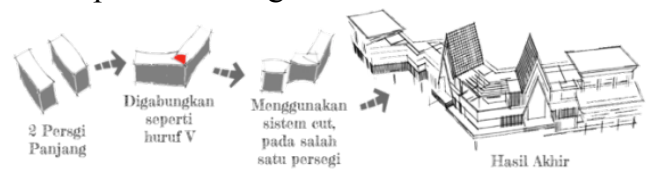

Gambar 24. Bentuk Bangunan Utama. (Sumber: Hasil Analisis Penulis)

5.11.3. Konsep Bentuk Bangunan Fasilitas Utama.

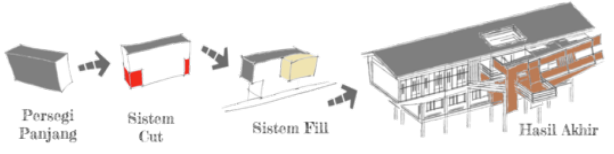

Gambar 25. Bentuk Bangunan Kamar Hotel. (Sumber: Hasil Analisis Penulis)

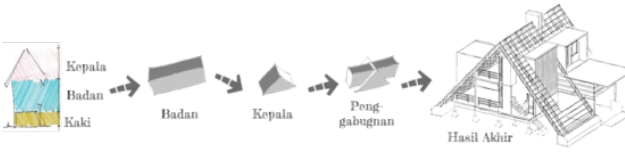

Gambar 26. Bentuk Bangunan Cottage. (Sumber: Hasil Analisis Penulis)

5.11.4. Konsep Bentuk Bangunan Zona Wisata Rekreasi.

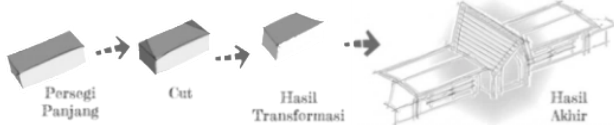

Gambar 29. Bentuk Bangunan Loket Tiket Water Park. (Sumber: Hasil Analisis Penulis)

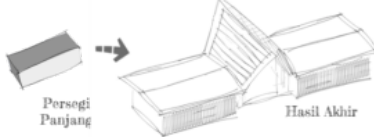

Gambar 30. Bentuk Bangunan Ruang Bilas (Sumber: Hasil Analisis Penulis)

5.11.5. Konsep Bentuk Bangunan Mercusuar dan Menara Pandang.

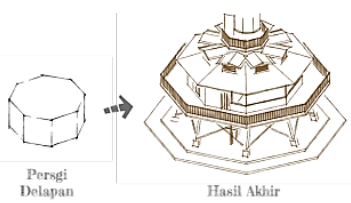

Gambar 31. Bentuk Bangunan Mercusuar dan Menara Pandang.

(Sumber: Hasil Analisis Penulis)

\subsection{Gambar Pra-rancangan.}

Gambar pra-rancangan ini merupakan hasil akhir dari metode penelitian yang telah di lakukan, berikut gambar pra-rancanngan dari Pengembangan Kawasan Objek Wisata Bono:

\subsubsection{Gambar Pra-rancangan Site Plan.}

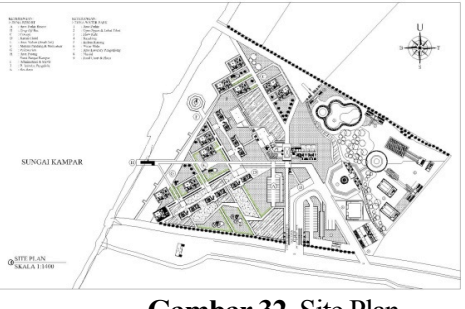

Gambar 32. Site Plan. (Sumber: Hasil Analisis Penulis)

3.12.2. Gambar Pra-rancangan Gate/Zona Penerimaan.

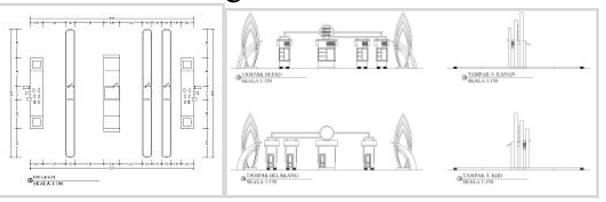

Gambar 33. Denah \& Tampak Gate. (Sumber: Hasil Analisis Penulis) 
3.12.3. Gambar Pra-rancangan Bangunan Utama.

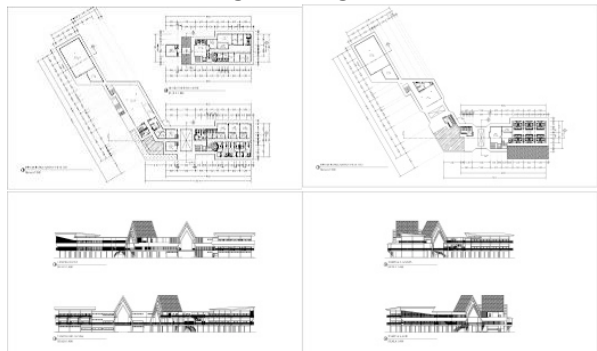

Gambar 34. Denah \& Tampak Bangunan Utama. (Sumber: Hasil Analisis Penulis)

3.12.4. Gambar Pra-rancangan Bangunan Fasilitas Utama.

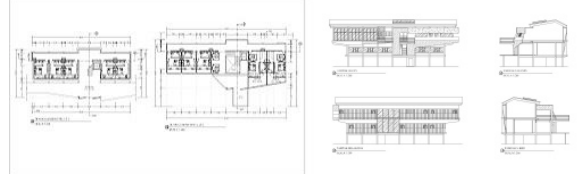

Gambar 35. Denah \& Tampak Kamar Hotel. (Sumber: Hasil Analisis Penulis)

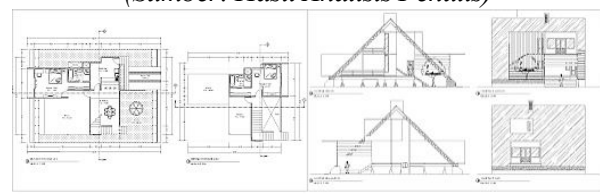

Gambar 36. Denah \& Tampak Cottage. (Sumber: Hasil Analisis Penulis)

3.12.5. Gambar Pra-rancangan Wisata Rekreasi.
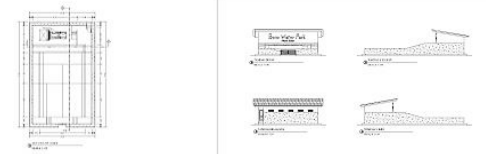

Gambar 39. Denah \& Tampak Flow Ride (Sumber: Hasil Analisis Penulis)

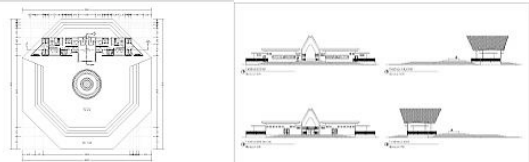

Gambar 40. Denah \& Tampak Loket Tiket Water Park. (Sumber: Hasil Analisis Penulis)
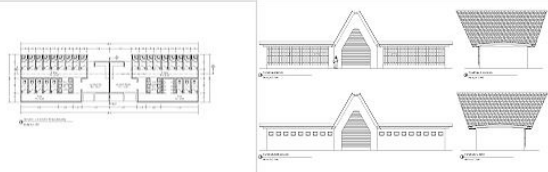

Gambar 41. Denah \& Tampak Ruang Bilas. (Sumber: Hasil Analisis Penulis)

3.12.6. Gambar Rancangan Menara Pandang dan Mercusuar.

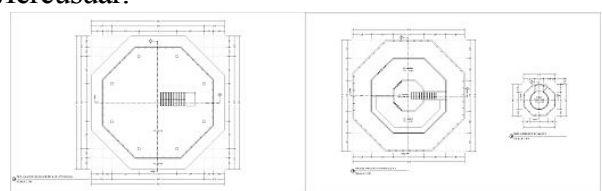

Gambar 42. Denah Menara Pandang \& Mercusuar. (Sumber: Hasil Analisis Penulis)

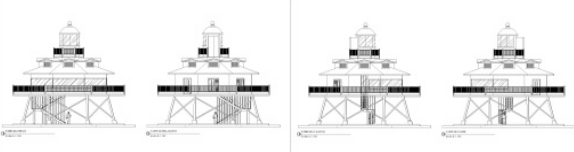

Gambar 43. Tampak Menara Pandang \& Mercusuar. (Sumber: Hasil Analisis Penulis)

\section{KESIMPULAN DAN SARAN}

\subsection{Kesimpulan.}

Perencanaan "Pengembangan Kawasan Objek Wisata Bono Teluk Meranti" adalah salah satu tahapan untuk menjadikan Kawasan Objek Wisata Bono menjadi tempat pariwisata yang dapat mewadahi segala kegiatan serta aktivitasnya. Sehingga berdasarkan penelitian yang telah penulis lakukan maka tersusunlah suatu Perencanaan dan Pemograman dari Pengembangan Kawasan Objek Wisata Bono Teluk Meranti.

\subsection{Saran.}

Berdasarkan kesimpulan dan uraian-uraian pada bab sebelumnya, maka penulis mencoba memberikan beberapa saran, yaitu

4.2.1. Kepada Pemerintahan Kabuparen Pelalawan untuk menerapkan suatu konsep pengembangan yang komprehensif, terpadu dan berkesinambungan agar Kawasan Objek Wisata Bono tersebut dapat berkembang menjadi lebih baik, melihat daya tarik yang terdapat pada kawasan sudah mulai tersebar luas.

4.2.2. Selain sarana akomodasi seperti area penginapan (hotel) masih banyak sarana dan prasarana yang kurang pada kawasan objek wisata bono ini yaitu seperti area makan (restaurant), terminal penghubung yang layak, dan sebagainya.

\section{DAFTAR PUSTAKA}

[1] Suwardjoko P. Warpana, Indira P. Warpani, "Pariwisata Dalam Tata Ruang Wilayah", (Bandung: ITB, 2007).

[2] Antoni Fadilla, "Pengembangan Kawasan Wisata Air Terjun Guruh Gemurai Kabupaten Kuantan Singingi”, Tesis Pascasarjana Universitas Lancang Kuning, (Pekanbaru: Perpustakaan Fakultas Teknik Arsitektur, 2012), hal. II-22.

[3] Ir. Sudarmin, M.T., “ Arsitektur Tradisional Melayu Riau”, Materi Perkuliahan Arsitektur Melayu Universitas Lancang Kuning.

[4] Samra, B. (2015). Konsep Ruang Dalam Rumah Lama di Kawasan Senapelan Pekanbaru. Jurnal Arsitektur Melayu dan Lingkungan, 2(1).

[5] Samra, B. (2017, December). The Characteristics Of Malay House Spatial Layout Of Pekanbaru In Accordance With Islamic Values. In IOP Conference Series: Earth and Environmental Science (Vol. 97, No. 1, p. 012049). IOP Publishing.

[6]PT. NUSA KARYA DUPAMA, Dinas Kebudayaan, Pariwisata, Pemuda Dan Olahraga Kabupaten Pelalawan, "Penyusunan DED Kawasan Objek Wisata Bono". 